\title{
Research on Port Logistics Synergy in Beijing-Tianjin-Hebei Region Under the Green Perspective
}

\author{
Chang Liu \\ School of Management, Tianjin University of Technology, Tianjin 300384, China \\ liuchangwugong@163.com
}

Keywords: Port logistics system, entropy method to determine the weight.

\begin{abstract}
The port in Beijing, Tianjin and Hebei is an important strategic node port of The Silk Road Economic Belt. This paper takes the port logistics system in Beijing, Tianjin and Hebei as the research object, establishes the synergetic theory model under the green perspective, selects the yearbook data from 2010-2016, uses the entropy method to determine the weight, calculates the port logistics coordination degree, And put forward the corresponding suggestions to improve the Beijing-TianjinHebei regional port logistics synergy. The results show that the synergy of port logistics in Beijing Tianjin - Hebei region is increasing, but the overall coordination degree is not high and needs further development.
\end{abstract}

\section{Introduction}

The port logistics system in Beijing, Tianjin and Hebei region carries the important mission of promoting the stable development of international trade in the north, and is a key step to promote the coordinated development in Beijing-Tianjin-Hebei integration. In 2015, the Central Political Bureau adopted the "Beijing-Tianjin-Hebei Collaborative Development Plan", and in the "Plan" that the promotion of Beijing-Tianjin-Hebei coordinated development is a national major strategy. Sun Bing said that the port industry is particularly important strategic resources in the local economic development. The competition is not only being in port industry, but also being in the whole region [1]. The port logistics in Beijing-Tianjin-Hebei region is the core strategic resource of regional synergistic development, which is very important for leading the economic development in BeijingTianjin-Hebei region.

\section{Literature Review}

Green development has become the theme of the development of the 21st century, the concept of Sustainable Development has gradually become the world of mutual learning and respected development model. British environmental economist Pierce defined "green economy" as a sustainable economy, and pointed out that starting from the environmental economy to study the sustainable development of the economy is the right path [2]. Lu Jin measured the coordination of the three systems in the four regions of China, and concluded that the resource consumption structure should be adjusted in the northeast and central regions of China, and the existing resource advantages should be transformed into the existing economic advantages. Change the traditional "high energy consumption, high pollution" is characterized by extensive development model [3]. Synergetic scholar Herman Hassan proposed in the 1970s with the aim of studying the evolution of complex systems from a number of subsystems from disorder to order [4]. Jiabao Wu based on the logistics of Jiangsu coastal port, this paper studies the multi-subject and multi-level structure of port in Jiangsu province, and on this basis, it studies the port logistics synergy model, but he neglects the influence of environmental factors on port synergy [5].

For this reason, this paper does the research under the perspective of green development first time, port logistics system in Beijing-Tianjin-Hebei regional as the object of study, establishes the synergetic theoretical model, selects the 2010 - 2016 yearbook data, uses entropy method to determine the weight of indicators, to calculates regional port logistics synergy. The paper aims to put forward 
the corresponding proposal to improve the Beijing-Tianjin-Hebei region port logistics development, which proposes some new ideas for Beijing-Tianjin-Hebei coordinated development.

\section{Research Method}

\subsection{Determine the Order Parameter}

Under the perspective of green development, consult the relevant experts, select the different indicators under the secondary indicators [5-6]. Port order of the logistics system can choose the following indicators reflect the collaborative cooperation. Here the "Port Water Resources Index" and "Port Energy Indicators" two parts in particular highlight the green development concept, the purpose is to more closely linked to the concept of green development and port logistics system, the BeijingTianjin-Hebei port logistics system index system is more comprehensive, as shown in Table 1.

Table 1.Port logistics system index system

\begin{tabular}{|c|c|}
\hline Level 1 indicators & Level 2 indicators \\
\hline $\begin{array}{l}\text { Port water environment } \\
\text { indexes-A1 }\end{array}$ & $\begin{array}{c}\text { Total amount of industrial waste water discharge (ten thousand tons)A11 } \\
\text { Industrial Ammonia Nitrogen Emissions (tonnes)A12 } \\
\text { Industrial Chemical Oxygen Demand (tonnes)A13 }\end{array}$ \\
\hline Port energy indexes-A2 & $\begin{array}{c}\text { Unit GDP energy consumption growth rate (\%)A21 } \\
\text { Unit GDP power consumption growth rate (\%)A22 } \\
\text { Unit Industrial added value Energy consumption growth rate (\%)A23 }\end{array}$ \\
\hline Port logistics indexes-A3 & $\begin{array}{c}\text { Pier length (m)A31 } \\
\text { Terminal berth (number)A32 } \\
\text { Container throughput (million international standard box)A33 }\end{array}$ \\
\hline $\begin{array}{l}\text { Hinterland economic } \\
\text { indexes-A4 }\end{array}$ & $\begin{array}{c}\text { Port hinterland GDP (billion)A41 } \\
\text { Hinterland foreign trade volume (billion dollars)A42 }\end{array}$ \\
\hline $\begin{array}{l}\text { Sustainable development } \\
\text { level-A5 }\end{array}$ & $\begin{array}{c}\text { GDP growth rate (\%)A51 } \\
\text { Container throughput growth rate (\%)A52 } \\
\text { Foreign trade growth rate (\%)A53 }\end{array}$ \\
\hline
\end{tabular}

\subsection{Empowerment of Indicators}

Taking into account the large differences in the article data, in order to make the data measured real and objective, to avoid subjective assumptions, the use of entropy method to determine the index weight.

\subsection{Order Parameter Order Degree Analysis}

1. Order Parameter Contribution Degree Calculation

Set order parameters in port logistics system $Q_{i j}$, set order parameters specific values $q_{i j}$, $i \in$ $[1, m], j \in[1, m] ; n$ is the number of samples, $m$ is the number of order parameters. $B_{i j} \leq q_{i j} \leq$ $A_{i j}$. The contribution of the subsystems to the system specific algorithm see formula (1)

$$
Q_{i j}=\left\{\begin{array}{l}
\frac{q_{i j}-B_{i j}}{A_{i j}-B_{i j}} \\
\frac{A_{i j}-q_{i j}}{A_{i j}-B_{i j}}
\end{array}\right.
$$

2. Ordinal Parameter Order Degree Calculation

The weight of each order parameter as $\omega_{j}$, set order parameter contribution as $Q_{i j}$, set order parameter $\mathrm{j}$ degree of order value $\mathrm{U}\left(\mathrm{Q}_{\mathrm{j}}\right)$, See formula (2)

$$
\mathrm{U}\left(\mathrm{Q}_{\mathrm{j}}\right)=\sum_{\mathrm{i}=1}^{\mathrm{n}} \omega_{\mathrm{j}} \mathrm{Q}_{\mathrm{ij}}
$$

We can see from the above formula, the larger the $U\left(Q_{j}\right)$ is, the higher the orderliness of the system is. On the other hand, the smaller $U\left(Q_{j}\right)$ is, the lower the order of the system is.

3. Degree of Coordination Calculation

Let the initial operation time of the port logistics system be t0. At this moment, the order of the port logistics system parameters is $U\left(Q_{j}\right)$, wherej $=1.2 \cdots \mathrm{m}$. After one cycle of its operation arrives at time $t 1$, the order of the system order parameters is $U\left(Q_{j}\right)$, where $j=1.2 \cdots \mathrm{m}$. Then the sequence of ordered degree is defined as $\mathrm{P}_{t}\left(\mathrm{Q}_{\mathrm{j}}\right)$, the coupling coefficient is $\mathrm{C}_{\mathrm{t}}$, See formula (3) (4).

$$
P_{t}\left(Q_{j}\right)=\left|U_{t}\left(Q_{j}\right)-U_{0}\left(Q_{j}\right)\right|
$$




$$
C_{t}=\sqrt[m]{\frac{P_{1} P_{2} \cdots P_{m}}{P_{1}+P_{2}+\cdots P_{m}}}
$$

Let the comprehensive coefficient of ordered sequence of sub-systems be $\mathrm{R}_{\mathrm{t}}$, let the cooperation degree of port logistics system be Dt, see formula(5)(6):

$$
\begin{gathered}
\mathrm{R}_{\mathrm{t}}=\sum_{\mathrm{j}=1}^{\mathrm{m}} \omega_{\mathrm{j}} \mathrm{P}_{\mathrm{t}}\left(\mathrm{Q}_{\mathrm{j}}\right) \\
\mathrm{D}_{\mathrm{t}}=\sqrt{\mathrm{C}_{\mathrm{t}} \mathrm{R}_{\mathrm{t}}}
\end{gathered}
$$

\section{Case Study}

Beijing-Tianjin-Hebei region has its own characteristics, for different locations, different hinterland economic advantages of the industry, with different resource advantages. Tianjin Port is located in the "Beijing-Tianjin-Hebei urban agglomeration" and "Bohai economic circle" of the intersection of the "China Northern International Shipping Center and the international logistics center," said the terminal length, berths and container throughput and other port logistics Indicators in the Beijing-Tianjin-Hebei region in a leading position in the port. Tangshan port is located in China The largest sea, the interface "Beijing-Tianjin-Hebei city group" to promote the Beijing-TianjinHebei region of iron and steel and petrochemical industry's foreign trade development. Qinhuangdao Port is China's "North Coal South transport" a major hub of the hub, is the famous north of the frozen port. In addition, in the "one way" important development strategy project, three ports at the same time is the "Silk Economic Zone" an important strategic node port. From the perspective of green development, for the port logistics, to enhance the port transport capacity, improve port productivity, and promote the coordinated development of Beijing and Tianjin.

\begin{tabular}{|c|c|c|}
\hline A level of indicators & Secondary indicators & Weights \\
\hline \multirow{3}{*}{ A1 } & $\mathrm{A} 11$ & 0.079 \\
\hline & A12 & 0.048 \\
\hline & A13 & 0.049 \\
\hline \multirow{3}{*}{$\mathrm{A} 2$} & A21 & 0.063 \\
\hline & A22 & 0.053 \\
\hline & A23 & 0.057 \\
\hline \multirow{3}{*}{ A3 } & A31 & 0.078 \\
\hline & A32 & 0.091 \\
\hline & A33 & 0.113 \\
\hline \multirow{2}{*}{ A4 } & A41 & 0.058 \\
\hline & A42 & 0.100 \\
\hline \multirow{3}{*}{ A5 } & A51 & 0.065 \\
\hline & A52 & 0.065 \\
\hline & A53 & 0.079 \\
\hline
\end{tabular}

\subsection{Determine the Weight}

Table 2. Port logistics system indicator weight

According to the analysis of Tabl2 , the weight of the environmental indicators (port water resources index A1 and port energy index A2 is 0.35, and it is an important indicator that the environmental efficiency index is relatively large in the whole port logistics system. Economic indicators (port logistics indicators A3, hinterland economic indicators A4) weight of 0.441 , in the port logistics system plays a decisive role. (9) Shows that the container throughput in the entire port logistics system plays a decisive role in the orderly level of the various places, and the container throughput of the port logistics index has the largest proportion. At the same time, container throughput is also a measure of a region's foreign economic and trade standards, is a regional economic capacity of the embodiment. The level of sustainable development (A5) is 0.209 , which is composed of environmental indicators and economic indicators. Only by the common development of environment and economy can the sustainable development of port logistics be realized.

\subsection{Synergy Evaluation and Analysis}

Table 3. Beijing-Tianjin-Hebei port logistics synergy

\begin{tabular}{ccccccc}
\hline Year & 2010 & 2011 & 2012 & 2013 & 2014 & 2015 \\
\hline Synergy & 0.418 & 0.435 & 0.427 & 0.488 & 0.491 & 0.500 \\
\hline
\end{tabular}




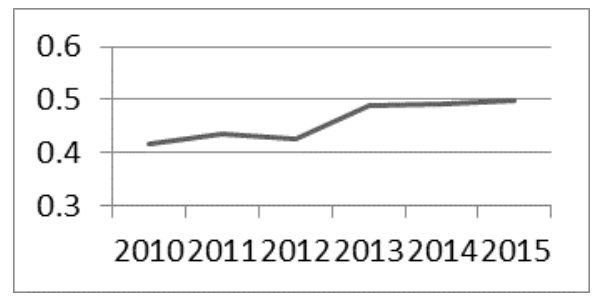

Fig 1. Beijing-Tianjin-Hebei port logistics synergy

The synergies of port logistics in Beijing-Tianjin-Hebei region are on the rise from the macro point of view, which shows that the major national strategy of Beijing-Tianjin-Hebei cooperation has played a catalytic role in the coordinated development of port logistics in the region, indicating that the macro-control measures promulgated by the government are obvious effect. The task allocation is unreasonable and the cooperation ability is general. Indicating that the synergy growth in 6 years is not obvious, there is no substantial increase, so the port should be based on the special natural advantages, the allocation of different tasks, assume different responsibilities, take different improvement measures to increase the growth rate. At the same time, it also shows that the BeijingTianjin-Hebei regional logistics and the development of collaborative development there is still much room for improvement in the context of the Beijing-Tianjin-Hebei region should be the use of existing resources to play the advantages of the port, their duties, effective Improve the port logistics synergy, so as to promote the Beijing-Tianjin-Hebei coordinated development.

\section{Suggestion}

According to the above analysis, according to the above synergy research results, this paper makes the following recommendations:

1. The implementation of a reasonable positioning of the port, to build the Beijing-Tianjin-Hebei regional port logistics alliance. In the context of the development of Beijing-Tianjin-Hebei cooperation should be clear on the three ports, optimize the layout, mutual cooperation, mutual benefit and win-win, and promote the Beijing-Tianjin-Hebei regional coalition coordinated development.

2. The development of port logistics at the same time pay attention to environmental protection, to create the Beijing-Tianjin-Hebei region green development model. First of all, the port industry is an important means of foreign exchange development and promotion of foreign trade. It is necessary to provide more green value and establish a positive image for the society. Secondly, the green development is the guiding ideology and the sustainable development of the new port is established.

3. Strengthen information exchange between ports and build a port information platform in Beijing, Tianjin and Hebei. Establish a port-specific informationization platform in Beijing, Tianjin and Hebei to break the existing "own problem-solving" mode in all ports and change the mode of "sharing resources and improving work efficiency."

In the context of the coordinated development of the Beijing-Tianjin-Hebei region, port logistics development is an important means to promote its development process. At the same time, it has played a supporting role in the coordinated development of the Beijing-Tianjin-Hebei region, and the two complement each other and promote each other. Based on the green development perspective, this paper establishes the theory model of synergetics, uses the entropy method to determine the weight, calculates the port logistics coordination degree in Beijing, Tianjin and Hebei region, and puts forward reasonable suggestions for the actual situation. And ultimately only the environment and the development of organic combination can achieve the sustainable development of port logistics.

\section{References}

[1]. Sun Bing. Research on the Regional Management Innovation of Beijing-Tianjin-Hebei Cooperative Development [J] .Management World, 2016, (07): 172-173.

[2]. Pierce waits. Green economy blueprint [M] Chuang Siu Fung translation etc. Beijing: Beijing Normal University Press, 1996.12 
[3]. QI Jin, CHANG Hong, WANG Yun-bo. Dynamic evolution of the coupling of energy, economy and environment in China [J]. China Population Resources and Environment, 2017, (02): 60-68.

[4]. Herman Haken, Ling Fuhua translation, "Synergy - the mystery of nature," Shanghai Translation Publishing House, 2001.

[5]. Research on Port Logistics Synergetic Mechanism Based on Multi-Agent: A Case Study of Jiangsu Coastal Port Logistics [J] .Management Science in China, 2014, (S1): 440-446.

[6]. Li Hong, Zhang Xiyuan. Research on the synergistic degree of regional ecological innovation and its influencing factors [J] .Chinese Journal of Population, Resources and Environment, 2016, (06): 43-51.

[7]. TANG Yan, LI Jian. ECONOMIC COOPERATION BETWEEN INDUSTRIAL REGENERATION AND EQUIPMENT MANUFACTURING - A Case Study of Tianjin City $[\mathrm{J}]$.

[8]. MUHAMMAD S, NACEUR K, GAZI S. Environmental Kuznets curve in an open economy: a bounds testing and causality analysis for Tunisia [J] .Renewable \& sustainable energy reviews, 2014, 34: 325-336. 